\title{
Investment and financial volatility in Latin America
}

\author{
Graciela Moguillansky \\ Economic Development \\ Division, ECLAC \\ gmoguillansky@eclac.cl \\ Financial liberalization and the lifting of capital market \\ restrictions have brought in foreign investment and made \\ more financing available for investment projects, but at the \\ same time have made it easier for financial crises originating \\ in Latin America or elsewhere to spread. Such crises became \\ more frequent in the $1990 \mathrm{~s}$, and as a result a more careful \\ study was made of the impact of capital flow instability on \\ investment. Hypotheses derived from theoretical procedures \\ were checked against econometric exercises showing that \\ capital flows have a positive impact, but that negative \\ consequences arise when they are volatile. This work covered \\ a large group of countries in the region.
}




\section{Introduction}

In the 1990s, investment growth in Latin America was unstable and the investment rate was low as a share of GDP, not only in comparison with high-growth developing countries but also when set against the performance of the region itself in the 30 years after the Second World War. This performance has to be viewed against the background of the economic changes that began in most countries around the mid-1980s, and that continued throughout the 1990s. These opened up the region's economies to trade and international financial flows and integrated them into the globalizing world economy.

This process involved the State withdrawing from production activities and reducing its role in investment financing, so that leadership passed to local and foreign private-sector actors. Contrary to what the supporters of economic reform hoped, however, the liberalization model has not succeeded in stabilizing investment growth or the investment rate. What the present article argues is that, as economies have opened up, the ability to obtain financing for large investment projects at times of international financial liquidity, beneficial though this is, has been offset by the volatility of capital flows, which can be abruptly reversed because of factors unconnected to the actual macroeconomic fundamentals of the countries. This disadvantage has been compounded by procyclical macroeconomic management.

This argument and the empirical evidence for it are detailed in the following sections. Firstly, section II depicts the new context in which local and foreign private-sector agents make their investment decisions. This is followed, in section III, by a description of the uncertainties associated with structural change that influence investment decisions. Section IV then analyses some stylized facts associated with the components of external financing, discriminating between the volatility of foreign direct investment (FDI) and other external resource transfers. Section V explains the mechanisms whereby capital flow volatility is transmitted to investment, and section VI presents the results of an empirical estimation of the investment function and the hypothesis test of the model, using a specification that includes traditional determinants supplemented by an explicit volatility indicator for external financial flows. Lastly, section VII sets forth the conclusions.

\section{II}

\section{The growth model and the new investment context}

From a historical perspective, the turn of the millennium has seen a major shift in Latin America's growth model. The shift that has been taking place is from the so-called import substitution model towards a model characterized by liberalized trade, finance and capital markets and by a reduced role for the State in production, finance and the overall direction of the economy.

This article is based on a document prepared to support the ECLAC paper Globalization and Development, LC/G.2157(SES.29/3), which was submitted at the twenty-ninth session of the Commission held in Brasilia from 6 to 10 May 2002.
Figure 1 gives growth rates for regional GDP and the investment ratio from 1950 onward (1950 was chosen because it is the earliest year from which consistent series are available). On average, the region's growth rate rose from $4.8 \%$ in the 1950 s to $5.7 \%$ in the $1960 \mathrm{~s}$ and $5.6 \%$ in the $1970 \mathrm{~s}$. The investment rate was consistently higher in the 1970 s, at $25 \%$ of GDP. These results were achieved despite the instability of the terms of trade and net external resource transfers, which were negative on average in the 1950s and 1960s.

In the 1970 s the region, and certain countries in particular, began to undergo a marked shift whose 
FIGURE 1

Latin America: GDP growth and the investment ratio, 1950-2000

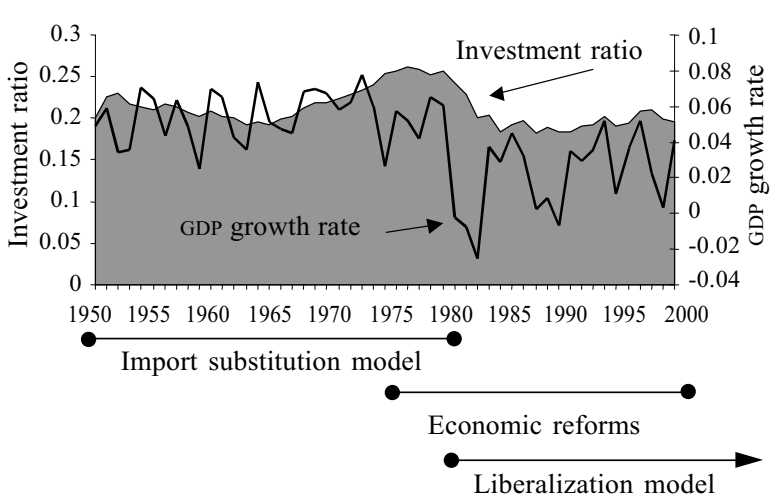

Source: ECLAC, Economic Development Division, prepared by the author.

causes were partly domestic (the crisis of the substitution model) and partly external.

The first oil shock and the international financial liquidity that resulted from it provided Latin American economies with a respite, allowing them to finance investment and grow through borrowing. But the external debt crisis and the reversal of capital flows -the first time the region had had experience of such volatility-affected all the countries severely, including those that had begun to liberalize and whose private sectors had borrowed in pursuit of near-term profits.
Growth rates in the 1980 s, as the countries struggled with the turbulent aftermath of the external debt crisis and the commencement of structural reform, were the lowest in half a century, and many of the social achievements of previous decades were swept away. At the same time, however, the transition to a new growth model was in progress. Henceforth, governments would look to the private sector for leadership and to exports as the key to a new form of participation in the international economy.

Over 15 years have now passed since the reforms began, and the results have not been encouraging. The region is still proving highly vulnerable in trade and financial matters. In only a few countries has investment increased across the whole range of export goods sectors, ${ }^{1}$ while in many others, chiefly in South America, capital has been directed towards sectors exporting primary goods or processed raw materials, whose extreme price volatility is compounding the weakness of external trade, just as it did in previous decades.

Furthermore, the weakness of manufacturing investment has reduced industrial GDP as a share of total GDP and worsened the sector's trade balance (except in Mexico and some Central American countries). As a result, investment and growth rates were lower in the 1990 s than in the 1950s, 1960s and 1970s, and growth was more unstable (see figure 1 again), a new factor in this being the volatility of capital flows.

\section{III \\ Structural change and uncertainties affecting investment decisions}

In most Latin American countries, economic reforms began amidst the turbulence generated by the external debt crisis. A number of the policies that shaped them were implemented as part of stabilization programmes (the liberalization of trade and finance, for instance, was included in the policy package alongside currency anchor systems), and their short-term effects were intertwined, producing signals that were sometimes consistent and sometimes inconsistent with the investment stimulus.

Although the countries progressed towards a new economic model, the years from 1990 to 1999 had the characteristics of a transition period. There were a number of reasons for this. Firstly, in those countries that introduced structural reforms in the $1990 \mathrm{~s}$ (Argentina, Brazil, Colombia and Peru), not enough time had passed for this new model to consolidate. As a result, investment decisions had to be taken in a climate of particular uncertainty.

Secondly, the reforms did not begin simultaneously. By and large, trade liberalization was the first reform

${ }^{1}$ See Moguillansky and Bielschowsky (2001) for a detailed analysis of sectoral investment in Latin America. 
to be implemented, and the privatization of public services the last. In some countries, the reforms were initiated simultaneously as a group, but in others the process was slow and the sequencing changed over time, making it difficult for the process as a whole to come to fruition. Brazil and Costa Rica are good examples of the latter.

Thirdly, reform was not carried forward steadily, which meant that economic agents had to cope with changing ground rules; a good example of this is the tendency of countries to introduce tariff surcharges and other obstacles to international trade after each balanceof-payments crisis.

Fourthly, the introduction of reforms at a time of profound imbalance in the system of relative prices and great economic instability enabled those industries that were quick to master short-term financial management to make speculative profits or survive in the market, but did not necessarily favour the most efficient producers or contribute to the long-term strength of the countries' economies. ${ }^{2}$

This response contributed to the crisis of the early 1980s and the rolling back of reform in several countries (Argentina and Chile were clear examples) as governments raised customs duties, introduced new capital market controls and intervened more heavily in the financial system and in companies with ties to banks.

The combination of an open capital market and domestic financial systems that were institutionally weak was not only destabilizing, but called macroeconomic policy into question and highlighted the fragility of the reforms that had been implemented. ${ }^{3}$

\footnotetext{
2 See Frenkel (1982); Frenkel and Damill (1987) and Kosacoff (1998).

${ }^{3}$ For further information see Ocampo, Bajraj and Martin (coords., 2002).
}

The recurrence of the phenomena described (in Mexico after the Tequila crisis and in Argentina and Brazil after the Asian and Russian crises) fuelled the suspicion that some aspects of the reforms had actually weakened the countries and made them less able to cope with the economic globalization and internationalization now prevalent in the world.

The initial deregulation of finance, stock markets and public services provision created problems that governments were gradually forced to address by taking regulatory measures and by amending and improving laws and institutions. Reforms were reoriented, creating new areas of uncertainty among economic agents and preventing them even now from following a clear line of action.

Financial liberalization provided the framework within which investment projects were pursued or blocked, depending on the type of company and sector. The financial crises of the 1990s involved all the countries in the region because of investors' perception of the contagion risk. Time and again, therefore, capital flight cut short both growth and investment financing. Meanwhile, the links between the real and financial economies have strengthened to such a degree that a crisis beginning in the real sector rapidly spreads to the financial sector and vice versa, reinforcing the adverse effects.

This combination of structural reforms, changes in the ground rules, capital transfer among sectors and external shocks of a new kind amplified by financial and capital market liberalization, and by globalization in general, not only created a new context, but translated into signals which encouraged investment in some cases and discouraged it in others. For this article we have chosen to look at one of these factors, the instability of capital and financing flows, with a view to analysing its investment impact in greater depth. 


\section{IV}

\section{Financial flows and investment: some stylized phenomena}

During the 1950s and 1960s, capital flows to developing countries were associated with international trade financing or with specific investments to finance real activities, or they were official funds from multilateral or bilateral bodies that offset terms of trade shocks. In the late 1960 s and early 1970 s, when eurodollars appeared, the international private-sector banking system undertook large-scale lending in Latin America. The external debt crisis and the efforts made to cope with it, particularly the Brady Plan, gave rise to markets for debt instruments and to the region's capital market.

On average, net fund transfers in the 1950s and 1960s were negative (figure 2). When the absolute figures are analysed, what is striking is not only the subsequent increase in capital flows, which rose from US\$ 4 billion in 1970 to a peak of US\$ 142 billion in 1998, but the change in their composition (table 1). The share of official flows fell from $23 \%$ of the total in 1970 to $0.4 \%$ in 2000 , while the composition of privatesector capital flows shifted towards portfolio investments (shares and bonds), whose share of the total rose from $1.3 \%$ to $20 \%$ between 1970 and 2000 , followed by FDI, whose share rose from $25 \%$ to $74 \%$ in the same period.

Some $80 \%$ of all FDI went to just four countries (Argentina, Brazil, Chile and Mexico), although as a percentage of GDP the impact on small countries was greater. Various studies (Ocampo, Bajraj and Martin (coords.), 2002 and ECLAC, 2001) have identified the motivations underlying the different business strategies that gave rise to this investment:

i) the quest for competitiveness in dynamic industries such as cars, electronics and wearing apparel (this was particularly the case with multinational companies in Mexico and the Caribbean);

ii) restructuring and modernization of production units in local and regional markets;

iii) investment deepening in sectors with natural comparative advantages (minerals and hydrocarbons), and

iv) acquisitions and modernization in infrastructure sectors with a view to breaking into regional markets.
FIGURE 2
Latin America and the Caribbean: Investment rates, growth and net resource transfers as a share of GDP
(Percentages)
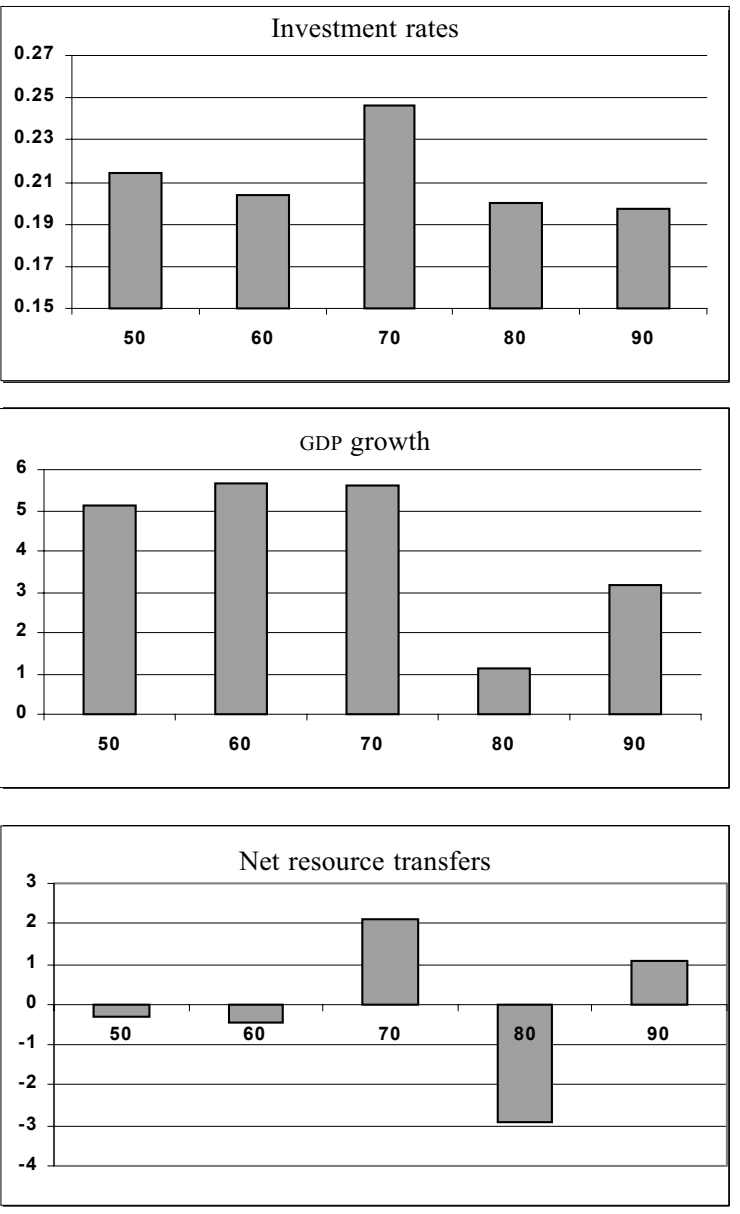

Source: ECLAC, Economic Development Division, prepared by the author.

A significant percentage of the FDI flowing into Latin America in the 1990s was intended for mergers, acquisitions and privatizations. The estimated figure for 1999 and 2000 is 50\%. Company acquisitions were supplemented, however, by capital to expand 
TABLE 1

Latin America: Capital flows

\begin{tabular}{|c|c|c|c|c|c|c|c|}
\hline & 1970 & 1980 & 1990 & 1995 & 1998 & 1999 & 2000 \\
\hline Total (billions of dollars) & 4.2 & 29.9 & 21.8 & 75.4 & 142.6 & 116.5 & 102.4 \\
\hline Official flows & 1.0 & 5.3 & 9.2 & 12.6 & 12.3 & 5.2 & 0.4 \\
\hline Private-sector flows & 3.3 & 24.6 & 12.6 & 62.8 & 130.2 & 111.3 & 102.0 \\
\hline Foreign direct investment & 1.1 & 6.1 & 8.2 & 29.8 & 72.1 & 90.4 & 76.2 \\
\hline Shares & 0.0 & 0.0 & 1.1 & 7.6 & 1.7 & 3.9 & 9.9 \\
\hline Bonds & 0.1 & 0.8 & 0.1 & 11.5 & 18.3 & 19.1 & 11.0 \\
\hline Commercial bank and other credits & 2.1 & 17.7 & 3.2 & 13.9 & 38.1 & -2.0 & 5.0 \\
\hline Total (percentages) & 100 & 100 & 100 & 100 & 100 & 100 & 100 \\
\hline Official flows & 23.2 & 17.7 & 42.1 & 16.8 & 8.7 & 4.5 & 0.4 \\
\hline Private-sector flows & 76.8 & 82.3 & 57.9 & 83.2 & 91.3 & 95.5 & 99.6 \\
\hline Foreign direct investment & 25.8 & 20.5 & 37.6 & 39.5 & 50.5 & 77.5 & 74.4 \\
\hline Shares & 0.0 & 0.0 & 5.1 & 10.1 & 1.2 & 3.3 & 9.6 \\
\hline Bonds & 1.3 & 2.7 & 0.5 & 15.2 & 12.8 & 16.4 & 10.7 \\
\hline Commercial bank and other credits & 49.7 & 59.1 & 14.8 & 18.4 & 26.7 & -1.7 & 4.9 \\
\hline
\end{tabular}

Source: World Bank (2001).

production capacity, modernize equipment and introduce leading-edge technology, particularly in infrastructure sectors (electricity and telecommunications), which helped to improve the region's systemic competitiveness.

In Latin America, FDI has been less volatile than net capital transfers overall, as the coefficient of variation shows (table 2). These figures are consistent with the conclusions of the study carried out by Sarno and Taylor (1999), who found that FDI was sensitive to long-term structural movements in a way that other forms of financing were not.

Hausmann and Fernández-Arias (2000a and 2000b) and Lipsey (2001) also concluded that FDI flows were less risky than debt or other financial flows, because they did not trigger crises. ${ }^{4}$

Conversely, portfolio flows and lending by the international financial system were highly volatile in the 1990s (table 3), being repatriated to the countries of origin not only when domestic conditions were unstable, but when shocks occurred in other countries or regions, examples being the Tequila crisis with its repercussions in Argentina and Brazil, the Asian crisis with its repercussions in the Southern Cone, and the Russian crisis with its region-wide repercussions. Only part of these flows was used to finance investment, as is demonstrated by the tendency for internal saving to

4 The findings of these studies contrast with those of Claessens, Dooley and Warner (1995), who found that FDI and short-term capital flows had the same degree of volatility, although their observations only covered a few countries.
TABLE 2

\section{Latin America: Coefficient of variation in foreign direct investment and net external resource transfers}

(Average for the period)

\begin{tabular}{lcccc}
\hline & $1980-1985$ & $1986-1989$ & $1990-1995$ & $1996-2000$ \\
\hline Foreign direct investment & 0.22 & 0.35 & 0.23 & 0.24 \\
Net resource transfers & 1.51 & 0.24 & 1.45 & 1.31 \\
\hline
\end{tabular}

Source: ECLAC, Balance of payments in 19 Latin American countries.

TABLE 3

Latin America: Coefficient of variation in financial flows in the 1990s

(Average for the period)

\begin{tabular}{lcc}
\hline & $1990-1995$ & $1996-2000$ \\
\hline Foreign direct investment & 0.23 & 0.24 \\
Shares & 0.62 & 0.69 \\
Bonds & 0.64 & 0.58 \\
Commercial bank and other credits & 1.03 & 0.89 \\
\hline
\end{tabular}

Source: ECLAC, Economic Development Division, prepared by the author on the basis of World Bank (2001).

be replaced by external saving (Uthoff and Titelman, 1997).

As figure 3 shows, there is an inverse relationship between the volatility of financing flows and the average investment ratio for Latin America. The period of least volatility (from the 1950s to the 1970s) coincides with a higher investment-to-GDP ratio. The correlation between the two variables is negative: $-22 \%$ for the period 1950 2000 , rising to $-44 \%$ between 1980 and 2000 . 
FIGURE 3

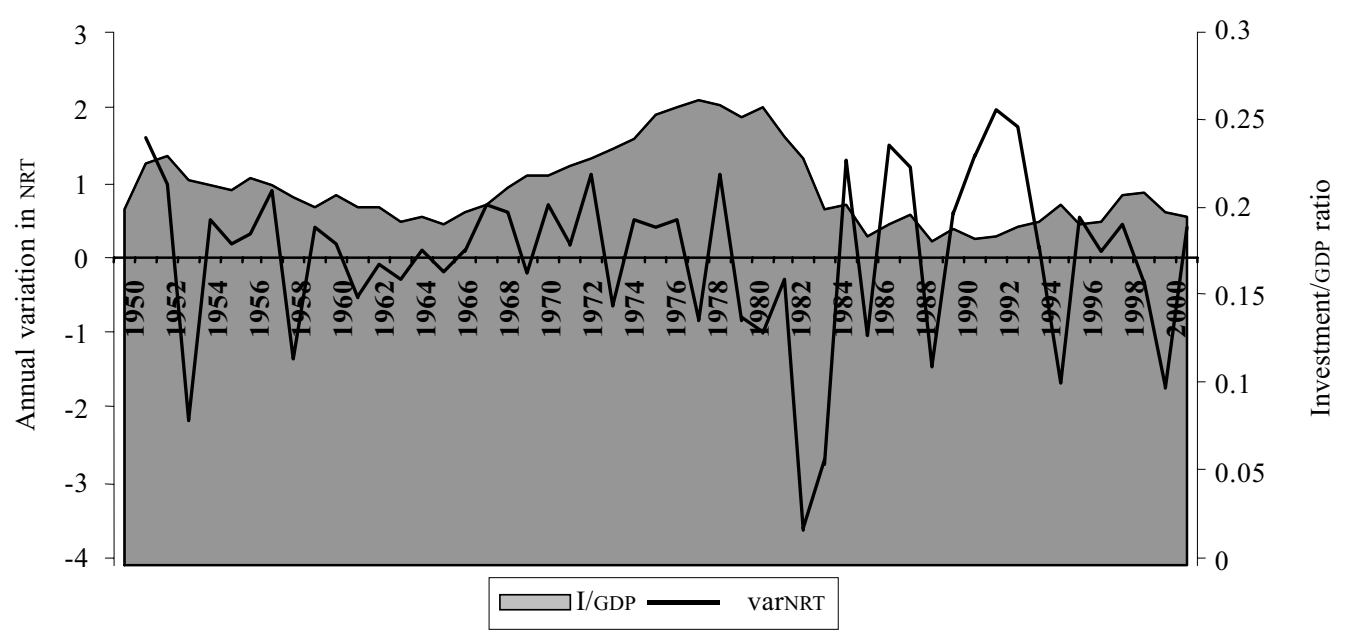

Source: ECLAC, Economic Development Division, prepared by the author.

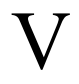

\section{Mechanisms whereby changes in capital flows are transmitted to investment}

In a context of financial openness and liberalization, changes in international capital flows affect both the monetary and exchange-rate policies and public spending, but the way they are transmitted depends on the assumptions of the analytical model and, in particular, on how open the capital account is and what exchange-rate regime is in place.

To simplify, we can start with a very straightforward general model: 5

$$
i=i^{*}+\left(E^{e}-E\right) / E+\lambda \varphi
$$

Equation [1] shows that the domestic interest rate $i$ depends on the international interest rate $i^{*}$, the expected rate of currency depreciation $\left(E^{e}-E\right) / E$ and a variable $\varphi$, which could represent the risk premium demanded by foreign investors to invest in developing countries (country risk).

\footnotetext{
${ }^{5}$ The model is based on the work of Claassen (1997) and Krugman and Obstfeld (2002).
}

If inflationary expectations $\Pi^{e}$ exist, $i$ is replaced by $\left(r+\Pi^{e}\right)$ and $i^{*}$ by $\left(r^{*}+\Pi^{e}\right)$ to give the equation for the real interest rate:

$$
r=r^{*}+\left(e^{e}-e\right) / e+\lambda \varphi
$$

(equilibrium in the financial market)

where $e$ is the real exchange rate and $e^{e}$ is the expected real exchange rate.

Then [1] can be written as:

$$
e=e^{e} /\left(1+r-r^{*}-\lambda \varphi\right)
$$

These equations are a financial approach for determining the real exchange rate, underscoring the role that this rate plays in balancing the expected returns from domestic and external financial assets.

In a small open economy, where domestic and international financial assets are perfect substitutes, any difference in the returns from such assets is immediately eliminated by exchange-rate movements. The difference in expected returns gives rise to capital flows. 
The immediate reaction of the exchange rate removes the interest-rate differential, returning the domestic and external rates to balance (parity interest rate). This is a short-term model that can explain daily, weekly or monthly changes in the exchange rate, assuming no intervention whatsoever by the financial authorities in the currency market.

From a longer-term macroeconomic point of view, taking the real economy into consideration, real exchange-rate movements operate in conjunction with other variables to balance the market for goods. In turn, macroeconomic equilibrium acts as an anchor for exchange-rate expectations in the financial market. At the same time, though, unless a situation of capital immobility prevails, macroeconomic determination of the exchange rate can be accompanied by a balanceof-payments current-account deficit or surplus, reflecting a change in net holdings of financial assets. To complete the model, then, we should add the equation for the goods market:

$$
\begin{gathered}
y=A(r, m)+B(A, e) \\
\text { (equilibrium in the goods market) }
\end{gathered}
$$

where $y$ is domestic supply, $A$ is the demand for locally produced and imported goods (consumption plus investment), which depends negatively on changes in the real interest rate and positively (wealth effect) on real liquidity $m$, and $B$ is the trade balance, which is a function of the absorption level and the real exchange rate.

Lastly, the equation that balances the money market is:

$$
\begin{gathered}
m=M / P=L(y, r) \\
\text { (equilibrium in the money market) }
\end{gathered}
$$

where $M$ is the money supply and $P$ is the price level.

This model can be used to identify the transmission mechanisms (changes in the domestic interest rate, expectations of devaluation or appreciation, inflationary pressures and changes in demand) that operate when there are fluctuations in international capital flows that ultimately affect the level of investment. The model works with different exchange-rate regimes, monetary policies (inflation targeting, money supply targeting, sterilization or non-sterilization) and levels of financial openness (controlled or uncontrolled capital flows).

Let us first assume a situation in which the capital account is completely open and the exchange-rate regime totally flexible, i.e., in which equations [2] and

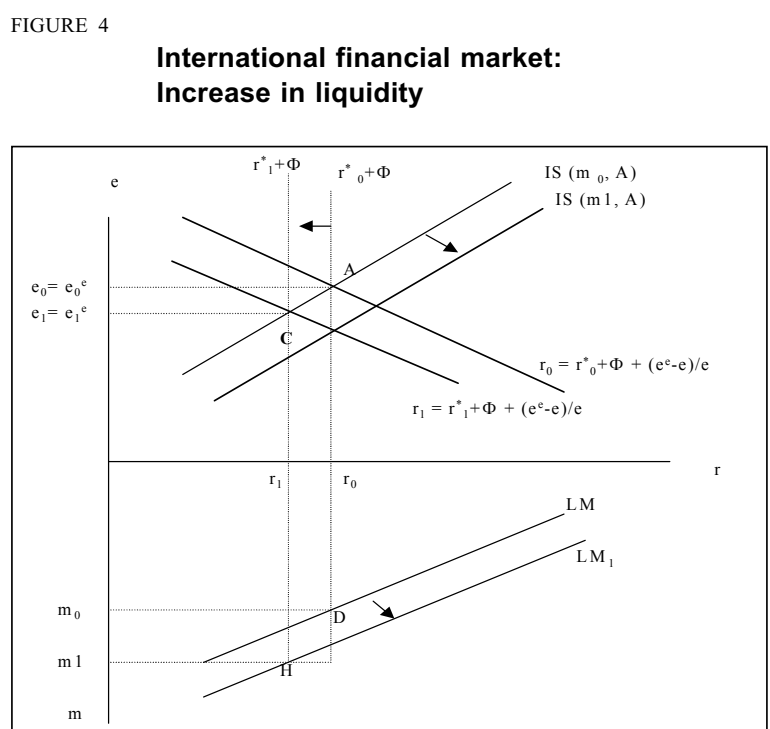

Source: ECLAC, Economic Development Division, prepared by the author, 2001.

[3] are operative. An increase in international financial liquidity, expressed in a lower international interest rate or a larger flow of capital into the region, will shift the equilibrium in the financial, real and money markets from point $A$ to point $C$ (figure 4).

This new equilibrium entails a larger supply of money and a fall in the domestic interest rate, the combination of which stimulates spending. At the same time, the influx of capital generates expectations of currency appreciation that will continue until the currency and money markets adjust to the new equilibrium (line $\left.r_{l}\right)$ in the financial market. If we isolate the investment function in the real market equilibrium equation we get:

$$
I=I(y, r, e)
$$

Both the higher spending and the lower interest rate are favourable to the implementation of new investment projects, while currency appreciation, although it reduces the cost of imported capital goods, lowers the returns of the export sector, thus discouraging its expansion. Whether the ultimate effect of the real exchange rate is positive or negative will depend on the elasticity and importance of the different sectors for capital formation.

If instead of increasing, international financial liquidity decreases and capital leaves the region because of some exogenous cause, the impact will be the 
opposite. If we were at a point such as $C$, the increase in the domestic interest rate and expectations of currency devaluation will create an equilibrium level at which spending is lower, such as point $A$, and the investment level will fall.

If the assumption of perfect capital mobility is replaced by controls on short-term capital movements, like those seen in Chile and Colombia for much of the 1990s, the effects of increased international financial liquidity will be less than shown in figure 4. Controls on capital movements act like a tax on capital, making it more costly, decreasing the return on flows and reducing expenditure. Because the tax is selective, it does not always affect investment directly. What it does do is prevent overheating in the economy and the subsequent adjustment. ${ }^{6}$

The monetary authorities can also neutralize the impact of the capital flow by implementing a sterilization policy, i.e., buying domestic assets to forestall changes in the money supply. In this case, the monetary effect of rising capital flows is reduced and financial market adjustment takes place primarily through changes in the real exchange rate. The specific monetary policy response will thus partly determine the eventual impact on investment.

If instead of a flexible exchange-rate regime the country has a fixed rate, economic agents will not expect any change in the price of the national currency when capital flows fluctuate. In this case, the adjustment variable in the financial market will be the domestic interest rate, and in the money market it will be the growth or contraction of the money supply resulting from changes in reserves.

Figure 5 shows the effect on spending of a capital outflow resulting from an external shock (international or regional financial crisis). Argentina in 2001 is a good example of this effect. The capital outflow creates expectations of a devaluation that would place the exchange rate at $E_{1}$, above $E_{0}$. The effect of these expectations on the line representing the financial market equilibrium is to shift it upward. To start with, the initial exchange rate remains at $r_{0}$, below the expected rate of return of deposits in external assets. To keep the exchange rate there, the Central Bank sells reserves, reducing the money supply and raising the interest rate. Spending shrinks, and so does investment. Capital continues to flow out until expectations of

${ }^{6}$ See Le Fort and Lehman (2000); De Gregorio, Edwards and Valdés (1999) and Valdés and Soto (1998).
FIGURE 5

\section{Latin America: Capital flight} and fixed exchange rate

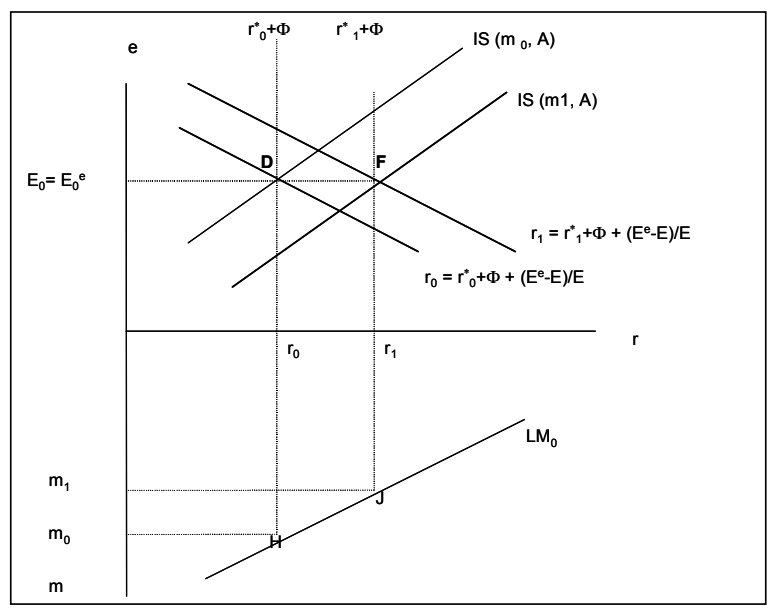

Source: ECLAC, Economic Development Division, prepared by the author, 2001.

devaluation cease and confidence in the national currency returns, except where country risk increases because of recession, as happened in Argentina.

Between the two systems analysed, the flexible exchange-rate system and the fixed-rate system (including convertibility systems), there are intermediate cases, such as when the authorities intervene to prevent the exchange rate from moving beyond pre-set fluctuation bands. In these cases adjustment takes place through the exchange rate and the interest rate. The results will depend on how much confidence economic agents feel in the policies being applied. Chile after the Asian crisis (late 1997 and 1998) offers a good example of conflict between expectations of devaluation and efforts to defend the currency. The outcome was an increase in interest rates that at times exceeded $100 \%$, albeit briefly.

What has been described so far is the mechanism whereby exogenous movements in capital flows are transmitted to macroeconomic variables, which in turn affect investment. The final effect will depend on how open the capital account is and on what monetary and/ or exchange-rate policy is being applied at the time. Like political or economic instability, however (see Pyndick, 1991), unexpected financial shocks increase uncertainty and make agents more risk-averse, and this is another way in which the volatility of capital flows affects investment. As uncertainty increases, agents are 
discouraged from implementing projects and become more likely to postpone them. Broadly speaking, the international financial crises of the 1990s show how important it is to treat uncertainty as a determining factor in investment decisions. At times of crisis, financial investors panic and withdraw capital not just from the country affected but from the entire region, or from all "emerging" countries. This reduces the liquidity of short- and long-term flows, while generating greater uncertainty in the real economy. ${ }^{7}$

From a microeconomic point of view, the relationship between the volatility of capital flows and investment is more complex and does not operate only in the indirect fashion described for the macroeconomic effects. Over the 1960s and 1970s, those who claimed to find links between financing and investment were divided into two schools of thought: the post-Keynesian school, which upheld the original ideas of Keynes, claiming that instability in financial relationships could make investment and the macroeconomy volatile, and the neo-Keynesian school, whose formal approach, based on optimization models derived from neoclassical principles, did not identify important links between financing and investment.

In the theories developed during the $1980 \mathrm{~s}$, the "new Keynesians" focused on the study of market imperfections and applied these ideas to credit markets. In this way, they came to the conclusion that the ability of companies to implement investment projects depended not only on the fundamentals of the project but also on their own financial position. This idea provided a new basis for understanding the relationship between the financial structure and real activity. ${ }^{8}$

Bernanke, Getler and Gilchrist (1996) analysed the way changes in credit market conditions amplify and spread the initial effects of real or monetary shocks. When there is a shock, companies whose balance sheets are weakened will have less access to credit than large companies or multinational conglomerates, a phenomenon that the authors term "flight to quality". The reorientation of lending acts as a financial accelerator, deepening the initial recession that resulted from the shock. The same mechanism can operate when international financial flows are reversed. In this case, instead of the flight to quality seen in the national

\footnotetext{
${ }^{7}$ See Heymann (2000) on learning in the expectations function.

${ }^{8}$ See Blinder and Stiglitz (1983); Myers and Majluf (1984); Bernanke and Getler (1995); Bernanke, Getler and Gilchrist (1996); Hubbard (1998); Fazzari, Hobbard and Petersen (1988 and 2000) and Carpenter and others (1998).
}

financial system, there is a flight to lower-risk countries, with similar effects on large companies in emerging countries.

The impact on balance sheets is transmitted through the borrower's higher debt servicing costs (in local and foreign currency), shrinking cashflow and weakening financial position. As many companies depend heavily on short-term borrowing to finance inventories and working capital, international volatility ends up by affecting cash flow in much the same way as a restrictive monetary policy would. At the same time, the higher domestic interest rates resulting from the contraction in external credit are associated with a fall in asset prices that, among other things, reduces the value of borrowers' collateral and their future borrowing capacity.

This leads us to derive the following equation, in which company cash flow $c$ is a function of spending $y$, cost of capital $r$, internal financing capacity $m$ and external financing $F$.

$$
c=f(y, m, r, F)
$$

In Latin America, and in developing countries generally, the financing capacity of companies with access to the international capital market improves when liquidity in this market increases. This affects companies' cash flow and influences their financing structure. The impact of financial outflows and/or financing restrictions resulting from an external shock will depend on the level of the company's existing external borrowings and on expectations before the crisis. If the economy was overheating and this led firms to overinvest, a sudden outflow of funds will lead to underutilization of production capacity and lower than expected returns. The deeper the crisis and the slower the recovery, the larger the losses will be and the companies will be less able to finance investment out of their own resources. If this is combined with a lower external and internal borrowing capacity or a higher cost of capital, investment rates will recover more slowly than they fell, so the volatility of capital flows will have asymmetrical effects.

Reflecting this analysis, equation [6] includes the direct effect of the variation in international capital flows derived from equation [7]. We thus get:

$$
I=f(y, r, e)+c(y, m, r, F)-g(u)
$$

where $u$ represents an indicator of uncertainty generated by the volatility of capital flows. 
These factors obviously do not affect all companies alike. In Latin America, it can be seen that financial markets are segmented, owing to the incompleteness of markets and information asymmetry, and that companies have different financing structures in terms of the breakdown among their own resources, debt instruments negotiated with the local financial system, and external debt. In general, small and medium-sized enterprises tend to finance themselves from their own resources and local bank borrowing, while large domestic companies and multinationals have access to local credit and to instruments supplied by the international financial market: bonds, shares or medium- and long-term external debt.

Access to the capital flows from the international financial system, and the reversal of such flows, affect both types of companies through different channels, but also have differentiated effects on large companies depending on whether they are export-oriented or produce for the local market:

i) Small and medium-sized enterprises: during crises, the decline in profits (which are essential for self-financing) is compounded by the constriction of bank lending caused by reduced liquidity in the local financial market and the greater reluctance of banks to take risks. A kind of crowding-out effect operates owing to the flight to quality referred to earlier. During upturns, on the other hand, the liquidity of the domestic financial system leads banks to invest in activities that might normally be considered too unprofitable and/or risky, and crowding in occurs. When flows are reversed, the business cycle is intensified by bankruptcies among companies that have taken on too much debt and the fragility of those that survive.

ii) Large export-oriented local or multinational companies: if the influx of capital prior to the financial shock led to currency appreciation, the subsequent devaluation will benefit them by making local currencydenominated wages and inputs cheaper. This will tend to make them more profitable, but at the same time they will be negatively affected by the lack of liquidity in the international financial market. What this generally means is that they are unable to raise money by issuing bonds or shares or by borrowing, or that it becomes much more expensive to do so, and investment projects are likely to be postponed as a result. The opposite happens during upturns, when investment projects become easier to implement.

iii) Large domestic market-oriented local or multinational companies: currency appreciation during the period of international financial liquidity benefits them and encourages external borrowing. If the company expects an outflow of external funds or a possible crisis, it may avoid currency risk by shifting part of its external borrowings into local-currency debt. If it fails to anticipate these developments it will be exposed to currency losses. Meanwhile, its access to external financing will be restricted, and if there is a sharp devaluation (because there was previously a fixed exchange rate or dirty float) this will be compounded by a large fall in profits, compromising its future creditworthiness. In this case, investment decisions will depend not only on the fundamentals of the project but also on the assessment that financiers make of the company, which may be faced with a domestic and external credit crunch.

To sum up, the effect of capital account liberalization and financial volatility will depend on how heavily the different types of companies are represented in the economy and in capital formation. If large exporters predominate the economy will be less affected, unless a very high proportion of exports go to markets that have also suffered from the international financial crisis (this was what happened to Chile with the Asian crisis).

It will also depend on how much domestic and external debt companies are carrying. If small and medium-sized enterprises are heavily in debt when capital flows are reversed and spending contracts, they will probably find it very hard to survive. In any event, it will be a long time before they are again in a position to expand production capacity.

Lastly, the scale of the impact will also depend on monetary policy and the exchange-rate regime. It has been shown on different occasions that adjustment is more traumatic for real variables (growth and employment) when exchange rates are fixed than when they are flexible. ${ }^{9}$ While spending clearly has a positive impact on investment and the cost of capital a negative one, abrupt changes in the real exchange rate do not automatically produce a positive or negative result. Rather, the impact depends on which are the markets that companies sell to and what type of effect predominates. If it is the financial effect, devaluation will have a negative impact. If it is the real effect, the impact is indeterminate: export sectors will become more profitable, but the cost of capital goods will rise, adversely affecting activities that are oriented towards the domestic market.

\footnotetext{
${ }^{9}$ See Ffrench-Davis and Larraín (2001).
} 
Future research may clarify the effects of international capital flow volatility on companies that have different levels of access to such funding, different financing structures and different sectoral orientations. The distinction between export- and local marketoriented sectors is particularly important.

\section{VI}

\section{Capital flow volatility and investment: empirical estimates}

This section presents the results of estimating an econometric model that seeks to explore the impact of capital flow variation and volatility on investment. ${ }^{10}$

The weight attached by agents to the recent past when forming future expectations, particularly as regards capital flows, led us to choose a partial adjustment model as the relevant specification for equation [8]. The way this type of model estimates expectations with a special emphasis on the recent past is consistent with the failure of businesses to project turning points in the behaviour of key variables, such as the suspension of flows or sudden devaluation, as they have tended to think that past tendencies will continue in the future. This has meant that external crises have caught them unawares, and in many cases with an excess of investment.

Because level variables are subject to spurious correlation owing to the powerful impact of the trend, differenced explanatory variables are included in the model estimation.

The definition of capital flows does not include FDI. The reason is that some of what is recorded as such is new investment used for gross capital formation in the countries, and is thus a component rather than a determinant of investment, so that it belongs on the lefthand side of the equation rather than the right. The remainder, being payment for assets, constitutes capital transfer rather than capital formation, so it should not be regarded as an investment determinant either.

In estimating the volatility of flows, all net external resource transfers were included. During domestic crises and external shocks there is a decline in all

\footnotetext{
${ }^{10}$ Although the model explicitly seeks to highlight financial factors as investment determinants, it also considers other factors included in empirical estimates for Latin American countries in the last three decades. See Serven and Solimano (1993); Rama (1993); Moguillansky (1996) and Agosin (1998).
}

components of external financing, and it is this that depresses investment. We included real exchange-rate volatility in the model as a supplementary indicator contributing to uncertainty. Like capital flow volatility, it is negative in its effects.

The model also includes two control variables. The first is the degree of trade liberalization, measured by the share of GDP accounted for by foreign trade (exports plus imports). Trade liberalization was regarded as an essential measure for stimulating exports because it lowers the cost of imported inputs and capital goods. Indirectly, it appears to have a positive influence on investment.

The second control variable used is a dummy variable for the 1980s which captures the investment recession brought on by the external debt crisis and the subsequent adjustment process until recovery took place.

The model was estimated using the panel method, applied to a total of 16 Latin American countries for which consistent variables and annual data covering the period 1970-2000 were available. Two methods of estimation with fixed coefficients were employed, the first using generalized least squares and incorporating the matrix of consistent standard errors and covariances obtained with White's method (1980), and the second using a consistent estimator for the presence of both heteroscedasticity and serial autocorrelation of errors. In this case the seemingly unrelated regression (SUR) method was used.

Table 4 presents the coefficients of the panel regressions on the basis of fixed effects and common coefficients for the explanatory variables, i.e., on the assumption that the investment function presents the same elasticities for the different countries. The signs of the variables are as expected and the coefficients are robust when the different methods of estimation are applied. 
Box 1

SPECIFICATION OF THE REGIONAL INVESTMENT MODEL

$$
\text { I_Y }=\mathrm{c}(1) \Delta \mathrm{GDP}+\mathrm{c}(2) \Delta \mathrm{XM} \_\mathrm{Y}+\mathrm{c}(3) \Delta \mathrm{RER}+\mathrm{c}(4) \Delta \mathrm{VRER}+\mathrm{c}(5) \Delta(\mathrm{OK})+\mathrm{c}(6) \Delta \mathrm{VF}+\mathrm{c}(7) \text { I_Y (-1) }
$$

Where:

I_Y : Investment to domestic output ratio.

GDP : Gross domestic product.

XM_Y : External trade (exports plus imports) as a share of GDP.

RER : Real exchange rate index.

VRER : Indicator of annual volatility in the real exchange rate, calculated from the coefficient of variation in the real monthly exchange rate.

OK : Net resource transfers from abroad as a percentage of GDP, excluding foreign direct investment.

VF : Indicator of capital flow volatility. Represents the annual variation in a moving average of the coefficient of variation for net resource transfer flows, calculated on a five-year basis.

$\Delta \quad$ : Delta operator, representing the first difference of the variable.

Source: ECLAC, Economic Development Division, prepared by the author, 2001.

TABLE 4

Results of the regional model for the investment function

\begin{tabular}{|c|c|c|c|c|}
\hline \multirow{3}{*}{$\begin{array}{l}\text { Dependent variable: I_Y } \\
\text { Explanatory variables: }\end{array}$} & \multicolumn{4}{|c|}{ Correction of } \\
\hline & \multicolumn{2}{|c|}{$\begin{array}{l}\text { Heteroscedasticity } \\
\text { (White, 1980) }\end{array}$} & \multicolumn{2}{|c|}{$\begin{array}{c}\text { Autocorrelation and } \\
\text { heteroscedasticity (SUR) }\end{array}$} \\
\hline & Coefficient & $\begin{array}{l}\text { Student's } \\
\text { t-statistic }\end{array}$ & Coefficient & $\begin{array}{l}\text { Student's } \\
\text { t-statistic }\end{array}$ \\
\hline$\Delta$ GDP $(-1)$ & 0.0076 & 7.62 & 0.0077 & 11.92 \\
\hline$\Delta \mathrm{XM} Y$ & 0.0019 & 4.72 & 0.0019 & 9.21 \\
\hline$\Delta \mathrm{XM}^{-} \mathrm{Y}(-1)$ & 0.0778 & 2.03 & 0.0528 & 2.39 \\
\hline$\Delta \mathrm{RER}$ & -0.0172 & -4.21 & -0.0166 & -8.48 \\
\hline$\Delta \operatorname{VRER}(-1)$ & -0.0002 & -0.03 & -0.0016 & -0.57 \\
\hline$\Delta \mathrm{OK}$ & 0.0064 & 4.74 & 0.0061 & 11.60 \\
\hline$\Delta \mathrm{VF}(-1)$ & -0.0011 & -3.49 & -0.0011 & -5.35 \\
\hline D8189 & -0.0186 & -2.15 & -0.0291 & -5.09 \\
\hline I_Y (-1) & 0.8262 & 34.76 & 0.8111 & 44.05 \\
\hline
\end{tabular}

Source: ECLAC, Economic Development Division, prepared by the author on the basis of appendices A and B.

The results show that in the region as a whole, taking the statistical information for 16 countries as a basis, it is possible to identify the significant impact that both the liquidity and the volatility of external financing have as determinants of investment. Variations in the availability of external capital and/or sudden changes of sign are captured by changes in aggregate investment, owing to the microeconomic effect transmitted by the reduced external borrowing capacity of large companies, the flight to quality in the domestic financial system (which results in a credit crunch for small and medium-sized enterprises), and the increase in uncertainty for economic agents.
The model estimates that through the direct channel of reduced financing, a reversal of $1 \%$ of GDP in capital flows results in a $0.64 \%$ reduction in investment as a share of regional output in the short term. If this reversal of flows makes them more volatile, causing greater uncertainty for economic agents, the result could be expressed as a further $0.11 \%$ fall in the investment ratio. These direct effects do not include the impact of reversal on spending, which is obtained from the model estimated using the Keynesian accelerator, and on the real exchange rate (increase in the cost of imported capital goods). A structural model would show this twofold impact. 


\section{VII}

\section{Summary and conclusions}

Financial and capital market liberalization has served to attract foreign investment and, in general, to expand investment project financing capabilities, but at the same time it has made it easier for financial crises originating in Latin America or elsewhere to spread. The frequency of these crises increased in the 1990s and growth and financing were cut off time and again, with the result that more careful study began to be made of the impact of capital flow instability on investment.

One stylized fact brought out by this article is that capital market liberalization led to a change in the composition of international capital flows into the region, with the share of official funds falling from $23 \%$ in 1970 to a minuscule amount in 2000. At the same time, FDI came to form the bulk of private-sector flows, averaging $40 \%$ or so in the mid- 1990 s and $74 \%$ in 2000 , although latterly less than $50 \%$ of this investment was used for fixed capital formation. The remainder merely represented asset transfers (i.e., payments for mergers, acquisitions or privatizations), part of a wave of capital concentration that is taking place in the world. Given that the region's investment ratio has been falling in recent years, it is possible that the counterpart of these flows -payments to acquire companies- is being invested outside the region.

The other stylized phenomenon is the great volatility of external capital flows other than FDI. These flows come from a variety of sources, including portfolio investments in the form of shares and bonds, short-term credits, and long-term international bank credits (associated in some cases with FDI), and one of their characteristics is that after being highly liquid in certain periods (particularly prior to the Tequila and Asian crises) they have been abruptly withdrawn in the midst of the crisis, causing serious financial and solvency problems in some of the region's countries.

Analysis of the mechanisms whereby the impact of capital flows and of periods of volatility in such flows is transmitted to investment reveals that, at the macroeconomic level, these variables affect the domestic interest rate, expectations of currency devaluation or appreciation, inflationary pressures and the combined effect that all this has on spending. The scale of the impact will depend, however, on the exchange-rate regime in force (which differs not only among countries in the region but within any given country at different times), on monetary policy (i.e., on whether or not inflation targeting, money supply targeting or sterilization policies are used) and on the degree of financial freedom (i.e., whether or not there are controls on capital flows). The way these policies are combined creates a context of greater or lesser vulnerability to a sudden capital drought or international financial crisis.

Besides the macroeconomic transmission mechanisms described, there is a microeconomic transmission mechanism that amplifies and spreads the initial effects of monetary or financial shocks, acting as a "financial accelerator". This mechanism works through two channels:

i) through greater access to cheap external credit and fewer restrictions on lending during boom periods, and through the "flight to quality", i.e., the redirecting of international finance to lower-risk countries, when a financial crisis occurs in the region or elsewhere. The result is a surge in the number of major investment projects executed in emerging countries, followed by a sudden contraction.

ii) through crowding out at times of crisis and crowding in during upturns. In the first case, banks concentrate their lending on large companies and crowd out small and medium-sized enterprises, something that is particularly harmful at times of low international liquidity. In the second case, large companies' access to external financing creates opportunities for smaller companies to obtain financing in the domestic banking market. Both the "flight to quality" among external financiers and the crowding out effect in the domestic financial system worsen the original recession resulting from any international financial crisis. At the same time, excessive borrowing among both small and large companies at times of strong financial liquidity plays its part in worsening the crisis when flows are reversed.

Like political or economic instability, unexpected financial shocks make agents more uncertain and riskaverse, and this is another way in which capital flow volatility affects investment. Increased uncertainty makes them more reluctant to implement projects, particularly those whose returns are expected only in the longer term. These include large infrastructure 
projects, which in the days before privatization were partially financed by loans from multilateral organizations and implemented by the State as a component of anticyclical policies.

To understand how widespread both financial volatility and the uncertainty determined by it are in Latin America, a panel model was estimated for 16 countries in the region, using statistics that cover the period 1970-2000. The specification took the form of a partial adjustment model, the idea being to capture the learning process among agents in relation to the expectations function. This is consistent with the failure of businesses to foresee turning points in capital flows and exchange-rate regimes, so that external crises have often caught them unawares and with an excess of investment. In addition to variables relating to the impact of external financing volatility, the model includes those variables that have normally been regarded as investment determinants in empirical estimates for the region.

The results show significant coefficients of variation in the liquidity and volatility of external financing. The model estimates that, by reducing the amount of financing available, a reversal of $1 \%$ of GDP in capital flows has the direct effect of cutting investment as a share of regional output by $0.64 \%$. If this reversal makes flows more volatile, increasing uncertainty among economic agents, the result could be expressed as a further $0.11 \%$ fall in the investment ratio. This still does not take into account the effect of flow reversal on spending, captured in the model by the Keynesian accelerator, and on the real exchange rate.

Not all companies have access to international financing, and the impact of an unforeseen flow reversal depends on the size of their existing domestic or external borrowings, on the extent of overheating in the economy, and on the monetary policy and exchangerate regime being applied when the crisis occurs. The conclusion this leads to is that the effect of volatility in international capital movements will differ not just among companies, but among countries as well.

To sum up, the exercise shows that opening a country up to the international capital market has a favourable effect on regional investment at times of financial liquidity, but that the instability and volatility of flows makes this a two-edged sword. One way of mitigating the adverse effects is to erect barriers to capital inflows at times of high liquidity, to prevent the economy overheating. ${ }^{11}$ Chile has done this successfully on a number of occasions. Another alternative is to apply anticyclical macroeconomic (fiscal and monetary) policies, although the scope of these is reduced by globalization. If the country is exposed to a liquidity trap, has little solvency in its financial system or operates a fixed exchange-rate regime in conjunction with a fully open capital market, monetary policy will be ineffective and then the fiscal instrument will have to be the basis of anticyclical policy. This requires sounder institutions, greater independence and more flexible fiscal policy than are to be found today in the Latin American countries. Lastly, the need to protect small and medium-sized enterprises' access to credit at times of crisis suggests that financial legislation and the role of development banking should be reviewed.

(Original: Spanish)

\footnotetext{
${ }^{11}$ See Valdés and Soto (1998); De Gregorio, Edwards and Valdés (1999) and Le Fort and Lehman (2000).
} 
APPENDIX A

Results of the regional model estimation: Correction of heteroscedasticity using White's matrix of covariances

\begin{tabular}{|c|c|c|c|c|}
\hline \multirow{4}{*}{\multicolumn{2}{|c|}{$\begin{array}{l}\text { Sample: } \\
\text { Dependent variable: } \\
\text { Number of serial observations: } \\
\text { Number of total balanced panel observations: }\end{array}$}} & \multicolumn{3}{|l|}{$1977-2000$} \\
\hline & & \multicolumn{2}{|l|}{ I_Y } & \\
\hline & & & \multirow[b]{3}{*}{ Prob. } \\
\hline & & \multicolumn{2}{|l|}{384} & \\
\hline Variable & Coefficient & Standard error & t-Statistic & \\
\hline$\Delta \_$GDP $(-1)$ & 0.0076 & 0.0010 & 7.62 & 0.000 \\
\hline$\Delta \mathrm{XM} \mathrm{M}_{-}$ & 0.0019 & 0.0004 & 4.72 & 0.000 \\
\hline$\Delta \mathrm{XM} Y \mathrm{Y}(-1)$ & 0.0778 & 0.0382 & 2.03 & 0.042 \\
\hline$\Delta \_$RER & -0.0172 & 0.0041 & -4.21 & 0.000 \\
\hline$\Delta$ _VRER $(-1)$ & -0.0002 & 0.0061 & -0.03 & 0.973 \\
\hline$\Delta \overline{\mathrm{O} K}$ & 0.0064 & 0.0013 & 4.74 & 0.000 \\
\hline$\Delta \mathrm{VF}(-1)$ & -0.0011 & 0.0003 & -3.49 & 0.000 \\
\hline D8189 & -0.0186 & 0.0086 & -2.15 & 0.031 \\
\hline I_Y $(-1)$ & 0.8263 & 0.0238 & 34.76 & 0.000 \\
\hline \multicolumn{5}{|l|}{ Fixed effects } \\
\hline Argentina-c & 0.3126 & & & \\
\hline Bolivia-c & 0.3333 & & & \\
\hline Brazil-c & 0.3238 & & & \\
\hline Chile-c & 0.2775 & & & \\
\hline Colombia-c & 0.3367 & & & \\
\hline Costa Rica-c & 0.2957 & & & \\
\hline Dominican Republic-c & 0.2762 & & & \\
\hline Ecuador-c & 0.3415 & & & \\
\hline El Salvador-c & 0.3374 & & & \\
\hline Guatemala-c & 0.4098 & & & \\
\hline Honduras-c & 0.2836 & & & \\
\hline Mexico-c & 0.3198 & & & \\
\hline Paraguay-c & 0.3008 & & & \\
\hline Peru-c & 0.2942 & & & \\
\hline Uruguay-c & 0.3641 & & & \\
\hline Venezuela-c & 0.3274 & & & \\
\hline \multicolumn{5}{|l|}{ Weighted statistics } \\
\hline $\mathrm{R}^{2}$ & 0.96 & \multicolumn{2}{|c|}{ Average of dependent var. } & -1.80 \\
\hline Adjusted $\mathrm{R}^{2}$ & 0.95 & \multicolumn{2}{|c|}{ Stand. dev. of dependent var. } & 0.42 \\
\hline Sum of squares of regression & 0.08 & \multicolumn{2}{|c|}{ Sum of squares of residuals } & 2.79 \\
\hline Logarithmic probability & 412 & \multicolumn{2}{|c|}{ F statistic } & 1089 \\
\hline Durbin-Watson statistic & 1.97 & \multicolumn{2}{|c|}{ Prob. (F statistic) } & 0.00 \\
\hline \multicolumn{5}{|l|}{ Unweighted statistics } \\
\hline $\mathrm{R}^{2}$ & 0.90 & \multicolumn{2}{|c|}{ Average of dependent var. } & -1.72 \\
\hline Adjusted $\mathrm{R}^{2}$ & 0.90 & \multicolumn{2}{|c|}{ Stand. var. of dependent var. } & 0.28 \\
\hline Sum of squares of regression & 0.08 & \multicolumn{2}{|c|}{ Sum of squares of residuals } & 2.81 \\
\hline Durbin-Watson statistic & 1.92 & & & \\
\hline
\end{tabular}

Source: ECLAC, Economic Development Division, prepared by the author. 
APPENDIX B

Results of the regional model estimation: Correction of heteroscedasticity and of autocorrelation in errors, sUR method ${ }^{\mathrm{a}}$

\begin{tabular}{|c|c|c|c|c|}
\hline \multicolumn{2}{|c|}{$\begin{array}{l}\text { Sample: } \\
\text { Dependent variable: } \\
\text { Number of serial observations: } \\
\text { Number of total balanced panel observations: }\end{array}$} & $\begin{array}{r}1977-2000 \\
\text { I_Y } \\
24 \\
384\end{array}$ & & \multirow[b]{2}{*}{ Prob. } \\
\hline Variable & Coefficient & Standard error & t-Statistic & \\
\hline$\Delta \_$GDP $(-1)$ & 0.0076 & 0.0010 & 7.62 & 0.000 \\
\hline$\Delta \mathrm{XM}$ Y Y & 0.0019 & 0.0004 & 4.72 & 0.000 \\
\hline$\Delta \mathrm{XM}_{-}^{-} \mathrm{Y}(-1)$ & 0.0528 & 0.0220 & 2.39 & 0.017 \\
\hline$\Delta \_\mathrm{RER}$ & -0.0166 & 0.0019 & -8.48 & 0.000 \\
\hline$\Delta-\operatorname{VRER}(-1)$ & -0.0016 & 0.0026 & -0.57 & 0.562 \\
\hline$\Delta \overline{\mathrm{O} K}$ & 0.0060 & 0.0005 & 11.60 & 0.000 \\
\hline$\Delta \_$VF $(-1)$ & -0.0011 & 0.0002 & -5.35 & 0.000 \\
\hline $\mathrm{D} 8189$ & -0.0290 & 0.0057 & -5.09 & 0.000 \\
\hline I_Y $(-1)$ & 0.8111 & 0.0184 & 44.05 & 0.000 \\
\hline \multicolumn{5}{|l|}{ Fixed effects } \\
\hline Argentina-c & 0.328 & & & \\
\hline Bolivia-c & 0.356 & & & \\
\hline Brazil-c & 0.343 & & & \\
\hline Chile-c & 0.295 & & & \\
\hline Colombia-c & 0.358 & & & \\
\hline Costa Rica-c & 0.313 & & & \\
\hline Dominican Republic-c & 0.293 & & & \\
\hline Ecuador-c & -0.364 & & & \\
\hline El Salvador-c & -0.359 & & & \\
\hline Guatemala-c & -0.438 & & & \\
\hline Honduras-c & -0.302 & & & \\
\hline Mexico-c & -0.337 & & & \\
\hline Paraguay-c & -0.318 & & & \\
\hline Peru-c & -0.311 & & & \\
\hline Uruguay-c & -0.388 & & & \\
\hline Venezuela-c & -0.347 & & & \\
\hline Logarithmic probability & 534.7596 & & & \\
\hline \multicolumn{5}{|l|}{ Unweighted statistics } \\
\hline $\mathrm{R}^{2}$ & 0.90 & \multicolumn{2}{|c|}{ Average of dependent var. } & -1.72 \\
\hline Adjusted $\mathrm{R}^{2}$ & 0.90 & \multicolumn{2}{|c|}{ Stand. dev. of dependent var. } & 0.28 \\
\hline Sum of squares of regression & 0.08 & \multicolumn{2}{|c|}{ Sum of squares of residuals } & 2.81 \\
\hline Durbin-Watson statistic & 1.89 & & & \\
\hline
\end{tabular}

Source: ECLAC, Economic Development Division, prepared by the author.

a SUR: Seemingly unrelated regression. 


\section{Bibliography}

Agosin, M. (1998): Capital Inflows and Investment Performance: Chile in the 1990s, in R. Ffrench-Davis and H. Reisen (eds.), Capital Flows and Investment Performance: Lessons from Latin America, Paris, Organisation for Economic Co-operation and Development (OECD) Development Centre/ECLAC.

Bernanke, B. and M. Getler (1995): Inside the black box: The credit channel of monetary policy transmission, Journal of Economic Perspectives, vol. 9, No. 4, Nashville, Tennessee, American Economic Association.

Bernanke, B., M. Getler and S. Gilchrist (1996): The financial accelerator and the flight to quality, The Review of Economics and Statistics, vol. 78, No. 1, Cambridge, Massachusetts, The MIT Press.

Blinder, A. and J. Stiglitz (1983): Money, credit constraints and economic activity, American Economic Review, vol. 73, No. 2, Nashville, Tennessee, American Economic Association.

Carpenter, R. and others (1998): Financing constraints and inventory investment: A comparative study with highfrequency panel data, Review of Economics and Statistics, vol. 80, No. 4, Cambridge, Massachusetts, The MIT Press.

Claassen, E. (1997): Global Monetary Economics, New York, Oxford University Press.

Claessens, S., M. Dooley and A. Warner (1995): Portfolio capital flows: Hot or cold?, The World Bank Economic Review, vol. 9, No. 1, Washington, D.C., World Bank.

De Gregorio, J., S. Edwards and R. Valdés (1999): Capital controls in Chile: An assessment, Santiago, Chile, Central Bank of Chile, March, unpublished.

ECLAC (2001): Foreign Investment in Latin America and the Caribbean, 2000 Report, LC/G.2125-P, Santiago, Chile.

Edwards, S. (1995): Crisis and Reform in Latin America, from Despair to Hope, New York, Oxford University Press.

Fazzari, S., R. Hobbard and B. Petersen (1988): Financing constraints and corporate investment, Brookings Papers on Economic Activity, No. 1, Washington, D.C., The Brookings Institution.

(2000): Investment-cash flow sensitivities are useful: A comment on Kaplan and Zingales, Quarterly Journal of Economics, vol. 115, No. 2, Cambridge, Massachusetts, The MIT Press.

Ffrench-Davis, R. (comp.) (2001): Financial Crises in "Successful" Emerging Economies, Washington, D.C., The Brookings Institution.

Ffrench-Davis, R. and G. Larraín (2001): How optimal are the extremes? Latin American exchange rate policies during the Asian crisis, Santiago, Chile, unpublished.

Ffrench-Davis, R. and J.A. Ocampo (2001): The globalization of financial volatility: Challenges for emerging economies, in R. Ffrench-Davis (comp.), Financial Crises in "Successful" Emerging Economies, Washington, D.C., The Brookings Institution.

Ffrench-Davis, R. and H. Reisen (eds.) (1998): Capital Flows and Investment Performance: Lessons from Latin America, Paris, OECD Development Centre/ECLAC.

Frenkel, R. (1982): Mercado financiero, expectativas cambiarias y movimientos de capital, Desarrollo económico, vol. 22, No. 87, Buenos Aires, Instituto de Desarrollo Económico y Social (IDES).
Frenkel, R. and M. Damill (1987): De la apertura a la crisis financiera. Un análisis de la experiencia argentina de 1977 1982, Ensayos económicos, No. 37, Buenos Aires, Central Bank of Argentina.

Hausmann, R. and E. Fernández-Arias (2000a): Is FDI a Safer Form of Financing?, Working papers, No. 416, Washington, D.C., Inter-American Development Bank (IDB).

(2000b): Foreign Direct Investment: Good Cholesterol?, Working papers, No. 417, Washington, D.C., IDB.

Heymann, D. (2000): Major macroeconomic disturbances, expectations and policy responses, CEPAL Review, No. 70, LC/G.2095-P, Santiago, Chile, ECLAC.

Hofman, A. (in the press): Capital Formation, Employment and Potential Output in Latin America: A Simplified Econometric Approach for the 1950-2000 Period, Santiago, Chile.

Hubbard, G. (1998): Capital market imperfections and investment, Journal of Economic Literature, vol. 36, No. 1, Nashville, Tennessee, American Economic Association.

Kosacoff, B. (1998): Estrategias empresariales y ajuste industrial, Buenos Aires, ECLAC Office in Buenos Aires.

Krugman, P. and M. Obstfeld (2002): International Economics: Theory and Policy, Boston, Addison Wesley.

Le Fort, G. and S. Lehman (2000): El encaje, los flujos de capitales y el gasto: una evaluación empírica, Documentos de trabajo, No. 64, Santiago, Chile, Central Bank of Chile.

Lipsey, R. (2001): Foreign Direct Investment in Three Financial Crises, Working papers, No. 84, Cambridge, Massachusetts, National Bureau of Economic Research (NBER).

Moguillansky, G. (1996): The macroeconomic context and investment: Latin America since 1980, CEPAL Review, No. 58, LC/G.1916-P, Santiago, Chile, ECLAC.

Moguillansky, G. and R. Bielschowsky (2001): Investment and Economic Reform in Latin America, Santiago, Chile, EClaC.

Morley, S., R. Machado and S. Pettinato (1999): Indexes of Structural Reform in Latin America, Reformas económicas series, No. 12, Santiago, Chile, ECLAC.

Myers, S.N. and N. Majluf (1984): Corporate financing and investing decisions when firms have information that investors do not have, Journal of Financial Economics, No. 3.

Ocampo, J.A. (coord.) (2002): Growth with stability: financing for development in the new international context, LC/G.2171-P, Santiago, Chile, ECLAC.

Ocampo, J.A. and C. Tovar (1999): Price-based capital account regulations: The Colombian experience, Financiamiento del desarrollo series. No. 87, Santiago, Chile, ECLAC.

Ocampo, J.A., R. Bajraj and J. Martin (coords.) (2002): A decade of light and shadow: Latin America and the Caribbean in the 1990s, Santiago, Chile, ECLAC.

Pyndick, R.S. (1991): Irreversibility, uncertainty, and investment, Journal of Economic Literature, vol. 29, No. 3, Nashville, Tennessee, American Economic Association.

Rama, M. (1993): Empirical investment equations for developing countries, in L. Serven and A. Solimano (eds.), Striving for Growth after Adjustment: The Role of Capital Formation, Washington, D.C., World Bank.

Sarno, L. and M.P. Taylor (1999): Hot money, accounting labels and the permanence of capital flows to developing countries: An empirical investigation, Journal of Development 
Economics, vol. 59, No. 2, Amsterdam, The Netherlands, Elsevier Science Publishers, B.V.

Serven, L. and A. Solimano (eds.) (1993): Striving for Growth after Adjustment: The Role of Capital Formation, Washington, D.C., World Bank.

Stiglitz, J.E. and A. Weiss (1981): Credit rationing in markets with imperfect information, American Economic Review, vol. 71, No. 3, Nashville, Tennessee, American Economic Association.

Uthoff A. and D. Titelman (1997): The Relation between Foreign and National Savings under Financial Liberalization, in R. Ffrench-Davis and H. Reisen (eds.), Capital Flows and Investment Performance: Lessons from Latin America, Paris, oECD Development Centre/ECLAC.
Valdés, S. and M. Soto (1998): ¿Es el control selectivo de capitales efectivo en Chile? Su efecto sobre el tipo de cambio real, Cuadernos de economía, year 33, No. 98, Santiago, Chile, Catholic University of Chile.

Villar, L. (2000): Manejo de auge y crisis financieras internacionales, in ECLAC, Hacia un sistema financiero internacional estable y predecible y su vinculación con el desarrollo social, Temas de coyuntura series, No. 8, Santiago, Chile.

White, H. (1980): A heteroskedasticity-consistent covariance matrix estimator and a direct test for heteroskedasticity, Econometrica, vol. 48, No. 4, Evanston, Illinois, The Econometric Society.

World Bank (2001): Global Development Finance, Washington, D.C. 